\title{
Determinants of Board Structure: Evidence from Australia
}

\author{
Reza Monem \\ Griffith University, Australia \\ Forthcoming in Journal of Contemporary Accounting and Economics
}

\begin{abstract}
Linck, Netter and Yang (2008) investigate the determinants of board structure in the high litigation-risk and low ownership-concentration environment of the U.S. In contrast, using a hand-collected data set of over 1,000 firms, this paper investigates the determinants of board structure in the low litigation-risk and high ownership-concentration environment of Australia. Multivariate analyses suggest that while board size and board independence are increasing in firm size, CEO duality is decreasing in firm size. Additional tests suggest that high ownership concentration increases board size, decreases board independence and increases CEO duality. These results imply that if high litigation-risk against directors (as in the U.S.) has a monitoring role in corporate governance, ownership concentration appears to offer an alternative governance mechanism in low-litigation-risk countries such as Australia.
\end{abstract}

JEL Classification: G34, M42

Key words: Corporate governance, ownership concentration, board of directors, board leadership, board independence, Australia

Correspondence: Reza Monem, Dept. of Accounting, Finance and Economics, Griffith University, 170 Kessels Road, Nathan, QLD 4111, Australia. Tel: +61 7 37353598. Fax: +61 7 37357960. Email:r.monem@griffith.edu.au

Acknowledgement: The author appreciates the constructive comments of an anonymous reviewer and the co-editor Bin Srinidhi. The author gratefully acknowledges the excellent research assistance of Dipak Keshwani and Jae Hun Kim. This research has been made possible with the financial assistance from the GBS Small Research Grant Scheme at Griffith University. 


\section{Determinants of Board Structure: Evidence from Australia}

\section{Introduction}

Corporate governance and its role in firm behaviour came under intense scrutiny following major corporate collapses around 2001-2002 (Clarke and Dean, 2007). New legislation and governance codes have emerged around the world aimed at improving governance practice (Demirag and Solomon, 2003; Clarke and Dean, 2007). Naturally, the research literature in corporate governance has experienced phenomenal growth in recent years. In particular, researchers have examined the role of corporate governance in business financing, firm performance, executive compensation, organisational structure, and firm value (see e.g., Gompers et al., 2003; Lemmon and Lins, 2003; Bhagat and Bolton, 2008; Bowen et al., 2008; Brown and Caylor, 2009; Giroud and Mueller, 2010; Chen et al., 2011; Larcker et al., 2011). Nevertheless, a central research question that has received very limited attention is how firms structure their board of directors (see Linck et al., 2008). Given that the board of directors is the highest executive committee in the firm, understanding what determines a board structure is fundamental toward understanding what role a board can play in firm behaviour. Using a large, hand-collected data set of over 1,000 firms in 2006, this paper investigates board structure in Australia and its cross-sectional determinants.

The literature on board structure is only emerging, and bulk of the evidence is based on U.S. data (e.g., Boone et al., 2007; Coles et al., 2008; Linck et al., 2008). In particular, Linck et al. (2008) is the most comprehensive study so far comprising 6,931 firms from 1990 to 2004. Linck et al. conclude that firms choose board structures based on the perceived costs and benefits of monitoring and advising roles, which tend to vary significantly across large and small firms. In particular, firms with high growth opportunities, high R\&D expenditures, and high stock return volatility have smaller and less independent boards, while larger firms 
tend to have larger and more independent boards (Linck et al., 2008). Further, while high managerial ownership is associated with less independent boards, the CEO occupies the board chair role in large firms and when the CEO is older and had have a longer tenure (Linck et al., 2008).

Aguilera and Jackson (2003) argue that isomorphic processes drive corporate governance practices to become more similar within countries and to differ across countries when institutional environments are nationally distinct. There are several differences in the institutional environments between the U.S. and Australia. Hence, the findings of Linck et al. (2008) and similar U.S. studies on board structure are not generalisable to Australia. For instance, although Australia and the U.S. are both Anglo-Saxon countries, corporate legal environments between these two countries differ in several fundamental ways.

First, '...the legal environment in the United States is uniquely hospitable to litigation against directors' (Cheffins and Black, 2006, p. 1393). Unlike in Australia, litigants in the U.S. pay their own legal expenses regardless of the outcome of court cases. Moreover, in a unique way, the U.S. legal system treats the attorneys of the plaintiff as entrepreneurs who search for legal violations and suitable clients rather than waiting for clients to come to them (Cheffins and Black, 2006). Further, attorneys in the U.S. usually recover their legal fees out of the settlement in successful class actions (Cheffins and Black, 2006). As a result, shareholder litigation is quite common in the U.S. ${ }^{1}$ In contrast, Australian company directors face a low-litigation environment. In particular, Australia has 'loser pays' civil litigation rules (Thai, 2002), and any damages recovered in a successful suit are paid to the company rather than the shareholder (Ramsay and Saunders, 2006). In addition, there is no U.S.-style provision for recovery of attorneys' fees from the company (Cheffins and Black, 2006). Further, there are restrictions on contingency fees, and high uncertainty on the viability of a

\footnotetext{
1 Over 1991-2004 period, 3,263 federal securities class action cases were filed in the U.S. federal courts with an average of over 230 cases each year (Cheffins and Black, 2006).
} 
class action unless each member of the plaintiff class has a claim against each defendant (Cheffins and Black, 2006). All these factors discourage securities lawsuits in Australia (Cheffins and Black, 2006). To the extent that legal and financial systems lead to disparity in corporate governance systems (Gillian and Starks, 2003), important differences between the U.S. and Australia in corporate legal environments would suggest differences in governance practices between these two countries.

Second, prior research suggests a strong connection between ownership structure and corporate governance practice. La Porta et al. (1998) argue that differences in legal environments may help explain why firms are financed and owned differently in different countries. They find a strong negative correlation between ownership concentration and the quality of legal protection of investors. Furthermore, Durnev and Kim (2005) provide evidence on the association between ownership concentration and corporate governance structure. Ownership is significantly concentrated in the non-U.S. countries than it is in the U.S. (Denis and McConnell, 2003). Based on their sample of 49 countries, La Porta et al. (1998) report that ownership concentration in Australia is much higher than that in the U.S. ${ }^{2}$ Thus, to the extent that ownership structure influences board structure, board structures between Australia and the U.S. are likely to be different.

Third, within the English-legal-origin countries, the U.S. firms are significantly much larger than firms in other countries such as Australia, Canada, Hong Kong, India, Malaysia, New Zealand, Singapore, and South Africa (La Porta et al., 1998). There is strong empirical evidence to suggest that corporate governance structure is influenced by firm size (Linck et al., 2008). Fourth, the labour market conditions between these two countries are remarkably different. Most large corporations in Australia are highly unionised, and trade unions play active roles in wage negotiations, management monitoring, and even shareholder

\footnotetext{
2 La Porta et al. (1998) report that the mean (median) ownership concentration, measured as the ownership by three largest shareholders, in Australia and the U.S. are $28 \%$ (28\%) and 20\% (12\%), respectively.
} 
activism (Rawling, 2006). Australia has ratified six of the eight core labour conventions (identified as fundamental labour rights by the ILO) including the freedom of association whereas the U.S. has ratified only two conventions but not the freedom of association (Adie and Sonder, 2004). ${ }^{3}$ In sum, due to significant differences in the institutional environments between Australia and the U.S. in terms of corporate legal environment (litigation risks), ownership structure, firm size and labour market conditions, findings on board structure in the U.S. cannot be entirely generalised to Australia. ${ }^{4}$

As discussed above, the role of ownership structure in corporate governance is likely to differ between high and low litigation-risk environments. If high-litigation risk is a deterrent to managers' rent-seeking behaviour, high ownership concentration is plausibly an investor response to discourage such behaviour in a low-litigation risk environment. Furthermore, ownership concentration is one way of enhancing private benefits of control to those who currently participate in control under the existing structure (Bebchuck and Roe, 1999).

In a high ownership-concentration firm, large-block shareholders have incentives to join the board of directors to enhance their both shared benefits and private benefits of control (Holderness, 2003). Hence, high ownership-concentration firms may be governed by large boards. Further, because high ownership concentration permits close monitoring of the management, it might reduce the demand for alternative monitoring mechanisms such as board independence and separation of the board chair from the CEO. In particular, ownership concentration may lead to a board structure that cannot be explained by economic

\footnotetext{
3 In total, as of March 2004, Australia has ratified 58 conventions (48 in force) whereas the U.S. has ratified only 14 conventions (12 in force) (Adie and Sonder, 2004). Arguably, the working class has always been a dominant political and social force in Australia. The labour movement in Australia gave birth to its largest political party, the Australian Labor Party.

${ }^{4}$ There are other differences in institutional environments between Australia and the U.S. Since the time of Federation, tariffs have been a contentious issue in Australian political life (Lloyd, 2008). Unlike in the U.S., Australian businesses have always enjoyed high tariff protection against foreign competition. In this environment, close government links of a director would be more valued by the firm than general business acumen. Moreover, the levels of sophistication of the managerial labour market and the market for corporate control, which likely affect corporate governance practice, are likely to differ between the U.S. and Australia. Finally, the Australian capital market has a shorter history and is much smaller compared with the U.S. capital market.
} 
characteristics of a firm. That is, high ownership concentration firms may have large but less-independent boards, and boards where the CEO is also the board chair.

Main results in the paper suggest that firm size is the single best predictor of board structure in Australia. While board size and board independence are increasing in firm size, CEO duality (i.e., the CEO is also the board chair) is decreasing in firm size. In addition, board size is increasing in the number of business segments, leverage level, and decreasing in firm profitability, market-to-book ratio, firm age, and CEO ownership. Board independence is increasing in firm leverage, director ownership, and CEO duality, but decreasing in the market-to-book ratio, volatility of stock returns, and CEO ownership. CEOs are likely to be board chairs in less-profitable firms, when the CEO is older or has longer tenure. Finally, high ownership concentration increases board size, decreases board independence and increases CEO duality.

While some of the results in this study are consistent with Linck et al. (2008), some results are significantly different. Similar to Linck et al. (2008), the determinants of board structure vary across small, medium, and large firms. However, the determinants of board structure appear to vary across ownership concentration levels as well. If high litigation risk against directors (as in the U.S.) has a monitoring role in corporate governance, ownership concentration appears to offer an alternative governance mechanism in lowlitigation-risk countries such as Australia.

In the U.S., the board chair and the CEO roles are combined in large firms, when the CEO is aged or has long tenure (Linck et al., 2008). In contrast, in Australia, CEO duality is increasing in smaller firms, less-profitable firms, CEO age, and CEO tenure. In the U.S., CEO duality is increasing in firm size whereas in Australia it is decreasing in firm size. In fact, the board is led by the CEO in around $51 \%$ of the small firms, $56 \%$ of the medium firms, and $71 \%$ of the large firms in the U.S. (Linck et al., 2008, p. 316). In contrast, the board is led 
by the CEO in only $48 \%$ of the small firms, $32 \%$ of medium firms, and $26 \%$ of large firms in Australia.

This paper contributes to the corporate governance literature in several ways. First, unlike the U.S. setting where litigation risk is high and ownership concentration is low, the Australian setting provides insight into board structure in a low-litigation-risk and highownership-concentration environment. As such, the results of this study can potentially shed light on the governance practice of other countries that exhibit corporate legal environments (with low risk of securities lawsuits), firm sizes, and ownership concentrations similar to Australia.

Second, this study directly investigates the cross-sectional determinants of board structure in a general context unlike other Australian studies that had addressed board structure in specific contexts (e.g., Hutchinson and Gul (2004) on investment opportunity set; Lim et al. (2007) on voluntary disclosure; Shekhar and Stapledon (2007) on initial public offerings). Third, this study employs the most-comprehensive and largest data set ever used in an Australian study. Fourth, the sample firms come from all industries, ages and are heterogeneous in size and profitability. Hence, the results are more likely to be generalisable.

The remainder of the paper is organised as follows. Section 2 provides a theoretical framework on the determinants of the board structure. Section 3 discusses the research methodology and the sample selection procedure. Section 4 discusses results of the empirical tests including robustness checks. Section 5 provides a summary of the paper and offers some conclusions.

\section{Theoretical framework and hypotheses}

The board of directors is the highest executive body in a firm. Two vital functions of the board are advising and management monitoring (Adams and Ferreira, 2007; Raheja, 
2005). Management monitoring involves guarding against harmful behaviour of management ranging from shirking to fraud (Linck et al., 2008). Advising involves helping top management in developing effective strategies and making business choices that enhance long-term growth and success of the firm. There can often be trade-offs between these two functions. Participation in a firm's strategic decisions requires inside knowledge of the firm (in addition to market and industry knowledge), and the process of acquiring inside knowledge could bring the board very close to the management. This, in turn, may compromise the board's ability to scrutinize management against harmful behaviour. Because there is no single optimal board structure for all firms, each firm will choose its board structure based on the potential costs and benefits of monitoring and advising given economic characteristics of the firm (Linck et al., 2008).

\subsection{Firm complexity and control benefits}

Both monitoring and advising functions are likely to be related to firm complexity (Linck et al., 2008). Thus, designing an optimal board for a complex firm would require bringing together talents and experts in different fields from outside the firm. These outsiders bring valuable expertise and connections to the firm. Thus, large firms with complex operating and financial structures or firms with geographically dispersed operations are likely to benefit from these outsiders, resulting in larger, independent boards (Boone et al., 2007; Coles et al., 2008; Linck et al., 2008).

Fama and Jensen (1983) argue that although monitoring costs increase in firm complexity, the benefits from effective monitoring should outweigh the monitoring costs. Firms with complex operating and financial structures or firms with dispersed operations are inherently likely to be large firms. These firms are also likely to be highly leveraged. Thus, to proxy for firm complexity, firm size, financial leverage, and the number of business segments are used (Booth and Deli, 1999; Bushman et al., 2004; Fama and Jensen, 1983; 
Linck et al., 2008). Firm age is also used as a proxy for firm complexity following Boone et al. (2007) and Linck et al. (2008). Following Linck et al. (2008), the regression models include the square of firm age to test whether firm age has a nonlinear relationship with board size and board independence.

Adams and Ferreira (2007) and Raheja (2005) document that board monitoring optimally increases with the level of private benefits available to managers, leading to boards that are more independent. Hence, following Jensen (1986), free cash flow is used as a proxy for private benefits.

\subsection{Advising and monitoring costs}

Not all firms are likely to be better off due to monitoring and advising of outsiders. Jensen (1993) argues that it is more costly to have large boards monitor growth firms. Adding outside directors to the board in these firms potentially increases free-rider problems, coordination costs, and compensation costs (Linck et al., 2008). More importantly, for firms with information asymmetry, it is costly to transfer firm-specific, proprietary information to outsiders (Maug, 1997). Fama and Jensen (1983) argue that firms with increased volatility of stock returns are more likely to have information unknown to outsiders. Thus, following Linck et al. (2008), I use the market-to-book ratio, the level of R\&D expenditure, and the standard deviation of monthly stock returns to proxy for advising and monitoring costs. Firms with higher market-to-book ratio and higher R\&D expenditures are likely to be firms with growth opportunities (Smith and Watts, 1992; Gaver and Gaver, 1993). Further, following Fama and Jensen (1983) and Linck et al. (2008), I use the standard deviation of stock returns to proxy for information asymmetry. Since monitoring and advising costs are likely to increase in these characteristics, board size and independence are expected to be decreasing in them. In contrast, growth option firms and high information-asymmetry firms 
are likely to give more power to the CEO by combining the board chair role with the CEO role.

\subsection{Ownership incentives and ownership concentration}

Boards are smaller in firms where insiders' and outsiders' (shareholders') incentives are aligned (Raheja, 2005). When such alignment exists, insiders require less monitoring from outsiders, resulting in less-independent boards. Raheja (2005) also argues that high ownership by outside directors leads to more benefits of verification suggesting lower verification costs, which, in turn, lead to larger and more independent boards. Following Linck et al. (2008), I use the percentage of shares held by the CEO (CEO Own) as a proxy for insider incentive alignment, and the percentage of shares held by nonexecutive directors as a proxy for outsider incentive alignment.

When ownership is concentrated, large shareholders have economic incentives to join the board to maximise their wealth and thereby, making the board larger. Further, monitoring by large shareholders reduces the demand for outside monitoring, making the board less independent. In this paper, ownership concentration is measured by the percentage of shares owned by the top twenty shareholders (Top20 Own). In a high ownership concentration firm, large-block shareholders have incentives to join the board of directors to enhance their both shared benefits and private benefits of control (Holderness, 2003). Hence, high ownership-concentration firms may be governed by large boards. Further, because high ownership concentration permits close monitoring of the management, it might reduce the demand for alternative monitoring mechanisms such as board independence and separation of the board chair from the CEO. That is, high ownership concentration firms may have large but less-independent boards, and boards where the CEO is also the board chair.

\subsection{CEO characteristics and board leadership}


Monitoring demand in a firm is inversely related to its size. Hence, smaller firms are more likely to have the board chair and the CEO roles combined to reflect low demand for monitoring in these firms. It is likely that CEO duality is increasing in CEO's bargaining power. Hermalin and Weisbach (1998) argue that board independence decreases the CEO’s bargaining power and that the CEO's perceived ability is the source of his/her bargaining power. CEO's perceived ability is increasing in firm performance and CEO tenure (Linck et al., 2008). Thus, the board chair and the CEO roles are also likely to be merged in high performance firms and when the CEO tenure is longer. CEO tenure is likely to be longer for older CEOs because older CEOs are likely to have longer management experience. Longer management experience may suggest higher perceived ability. Further, a CEO who is confident of his/her ability to deliver performance will likely restrict the board size to avoid undue outside influence and to reduce the monitoring costs associated with the outsiders. Thus, board size and board independence are decreasing in firm performance. In this paper, firm performance is defined as the ratio of earnings before interest and tax to beginning-ofperiod total assets (ROA).

Following Linck et al. (2008), I use the market-to-book ratio, R\&D expenditures, and the standard deviation of stock returns to capture the effect of CEO's firm-specific knowledge on board leadership. I expect CEO duality to be increasing in these characteristics.

In this study, board structure is measured along the dimensions of board size, board independence and board leadership (i.e., whether the CEO is also the board chair, also known as CEO duality). Board size is measured by the number of all board members including the CEO and the board chair. Board independence is the proportion of nonexecutive directors in the board. Board leadership (CEO duality) is a dummy variable, which takes a value of one if the CEO is also the board chair and zero otherwise. 


\section{Research methodology and sample selection}

\subsection{Methodology}

In light of discussion in section 2, the following models are estimated to identify the determinants of the board structure:

$$
\begin{gathered}
\text { Board Size }=\alpha+\beta_{1} \text { LnMVE }+\beta_{2} \text { ROA }+\beta_{3} \text { LnSegments }+\beta_{4} L E V+ \\
\beta_{5} \text { FirmAge }+\beta_{6} \text { FirmAge }+\beta_{8} M T B+\beta_{9} R \& D+\beta_{10} \text { STDRET }+\beta_{11} \text { CEO Own }+ \\
\beta_{12} \text { DirectorOwn }+\beta_{13} \text { Top } 20 \text { Own }+ \text { Industry Dummies }+\varepsilon \\
\text { Board Independence }=\propto+\beta_{1} \text { LnMVE }+\beta_{2} \text { ROA }+\beta_{3} \text { LnSegments }+\beta_{4} \text { LEV }+ \\
\beta_{5} \text { FirmAge }+\beta_{6} \text { FirmAge }{ }^{2}+\beta_{7} \text { MTB }+\beta_{8} R \& D+\beta_{9} \text { STDRET } \\
+\beta_{10} \text { Top20 Own }+\beta_{11} \text { Free Cashflow }+\beta_{12} \text { CEO Chair }+ \text { Industry Dummies } \\
\text { CEO Duality }=\propto+\beta_{1} \text { LnMVE }+\beta_{2} \text { ROA }+\beta_{3} \text { MTB }+\beta_{4} R \& D+\beta_{5} \text { STDRET }+ \\
\beta_{6} \text { Top20 Own }+\beta_{7} \text { CEOAge }+\beta_{8} \text { CEO Tenure }+ \text { Industry Dummies }+\vartheta
\end{gathered}
$$

where Board Size $=$ The number of directors in the board including the board chair and the CEO; Board Independence = The proportion of nonexecutive directors in the board; CEO Duality = A dummy variable taking the value of one if the CEO and the board chair are the same person and zero otherwise; $L n M V E$ = Natural logarithm of market value of equity (proxy for firm size); $R O A$ = Earnings before interest and taxes divided by beginning of year total assets (proxy for firm performance); LnSegments = Natural logarithm of the number of business segments; Leverage $=$ Total liabilities/Total assets; FirmAge $=$ The period from initial listing at the Australian Securities Exchange to the end of 2006 fiscal-year; FirmAge ${ }^{2}$ = FirmAge squared; $M T B=$ The market-to-book ratio of equity; $R \& D=\mathrm{R} \& \mathrm{D}$ expenditure scaled by total assets; STDRET = Standard deviation of monthly stock returns over the preceding year; CEO Own = The percent of firm shares held by the CEO; Director Own = 
The percent of firm shares held by the nonexecutive directors; Top20 Own = The percent of shares owned by the top 20 shareholders in the firm; Free Cashflow = Operating cash flow less net capital investments during the year scaled by total assets; Industry Dummies = Dummy variables to capture the differences in board structure due to industry characteristics; Industry classification is based on Standard \& Poor's two-digit Global Industry Classification Scheme (GICS); $\varepsilon, \varphi, \vartheta=$ error terms.

The following procedure is followed for data analysis. First, descriptive statistics are computed on board structure, firm characteristics and ownership characteristics. Then board size, board independence and CEO duality are regressed on firm characteristics. Ordinary least squares (OLS) regressions are estimated for board size and independence. But binary logistic regression is estimated for CEO duality as it is a binary variable. Additional tests are conducted on partitioned subsamples as robustness checks to complement the full sample analysis.

\subsection{Sample selection}

The initial sampling frame for this study consisted of all the 1,736 domestic firms listed in the ASX on 31 December 2006. Data for this study were collected from three different sources: corporate governance data were hand-collected from Connect 4 Annual Report database; financial statement variables were collected from AspectHuntley FinAnalysis database; data on share price, market-to-book ratio, and $R \& D$ were collected from Datastream. For 2006, Connect 4 Annual Report database contained annual reports only for 1,509 companies. Because of missing balance sheet information, four firms were deleted from the sample leaving 1,505 firms. Data screening revealed that 101 firms had $R O A>$ $+100 \%$, or $R O A<-100 \%$ and another 46 firms had leverage ratio $>1$. These observations were considered outliers. To minimise the effect of outliers, a 90\% winsorization was performed on these two variables. Due to missing data for several variables, the number of 
observations used in various tests vary such as market value of equity: 1,150 firms, shareholding by the CEO: 1,094 firms, and shareholding by nonexecutive directors: 1,096 firms, and CEO age and tenure: 448 firms. Despite such data attrition, some of the main tests in this study employ the largest sample ever used in an Australian study on corporate governance ( $N>1,000$ firms). Almost all previous Australian studies on corporate governance were restricted to samples well below 500 firms.

\section{Results and discussion}

This section describes the sample characteristics and discusses the results of empirical tests including additional tests to check robustness of the main results.

\subsection{Descriptive statistics}

Table 1 reports firm and governance characteristics of the sample firms in 2006. The mean (median) market value of equity (MVE) in 2006 was A $\$ 984.6(\mathrm{~A} \$ 47.0)^{5}$ million while the mean (median) book value of total assets (TAS) was A\$763.9 (A \$28.6) million. Both MVE and TAS are positively skewed with the means exceeding not only the medians but also the third quartiles.

Apart from firm age and the number of business segments, there are several notable differences between the sample in this study and Linck et al.'s (2008) sample. ${ }^{6}$ The U.S. firms are much larger compared to Australian firms. Linck et al.’s (2008) sample firms have a mean (median) TAS of U.S. $\$ 1.58$ billion (U.S. \$127 million) and mean (median) MVE of U.S.\$1.62 billion (U.S.\$105 million). ${ }^{7}$ Further, the mean (median) leverage in this sample is 34.9\% (29.6\%) compared to 43.8\% (40.9\%) in Linck et al. sample. In addition, the U.S. firms are more profitable than Australian firms. Mean (median) $R O A$ is $-12.94 \%(-2.07 \%)$

\footnotetext{
${ }^{5} \mathrm{~A} \$=$ Australian dollar.

${ }^{6}$ Comparison is made only with Linck et al. (2008), because their study is the most comprehensive U.S. study to date on board structure.

${ }^{7}$ The sample period in Linck et al. (2008) is 1990-2004.
} 
whereas in the Linck et al. sample it is $-2 \%(1.1 \%){ }^{8} \quad$ Mean (median) market-to-book ratio (MTB) is 2.14 (1.24) compared to 2.29 (1.47) in the Linck et al. (2008) sample.

In terms of ownership characteristics, mean (median) CEO ownership is $7.41 \%(0.90 \%)$ while the nonexecutive directors as a whole own $7.09 \%(0.80 \%)$ of firm shares. These numbers are $6.07 \%(0.97 \%)$ and $0.44 \%(0.02 \%)$ respectively, in the Linck et al. (2008) sample. Ownership concentration is high in Australia with mean (median) shareholding of 63.68\% (64.85\%) of firm shares by the Top20 shareholders (Top20 Own). Even in the least (ownership) concentrated $25 \%$ of the sample firms, Top20 Own is greater than $50 \%$.

Among the board structure variables, mean (median) board size is 4.92 (5). Australian boards are much smaller compared to the U.S. boards with a mean (median) board size of 7.5 (7) in Linck et al. (2008). A typical board in Australia has about three nonexecutive directors and two-thirds of the board members are nonexecutive members. In 35\% of the sample firms, the CEO is the board chair. In contrast, the CEO is the board chair in $58.3 \%$ of the sample firms in Linck et al. (2008). Thus, there are significant differences in board structure between Australia and the U.S.

\section{TAKE IN TABLE 1 ABOUT HERE}

Bi-variate Pearson's correlations suggest that larger firms $(r=0.603, p<0.001)$, older firms ( $r=0.077, p<0.005)$, more complex firms ( $r=0.316, p<0.001)$, more profitable firms ( $r=0.307, p<0.001)$, more leveraged firms $(r=0.238, p<0.001)$, firms with higher MTB ( $r$ $=0.060, p<0.001)$, firms with smaller ownership by the CEO $(r=-0.101, p<0.005)$, firms with lesser volatility of stock returns ( $r=-0.297, p<0.001$ ), and firms with higher ownership concentration $(r=104, p<0.001)$ have larger boards. Similarly, larger firms $(r=0.207, p$ $<0.001)$, more complex firms $(r=0.074, \quad p<0.001)$, more profitable firms $(r=0.076, \quad p$ $<0.001$ ), more leveraged firms ( $r=0.082, p<0.001$ ), firms with smaller CEO ownership ( $r=$

\footnotetext{
${ }^{8}$ The difference in performance will hold although Linck et al. (2008) use slightly different definition of performance.
} 
-0.101, $p<0.005)$, firms with more director ownership $(r=0.070, p<0.005)$, and firms with lesser volatility of stock returns $(r=-0.178, p<0.001)$ have more independent boards.

Larger boards are more independent $(r=0.225, p<0.001)$ and in larger boards, the CEO role is separated from the board chair $(r=-0.313, p<0.001)$. But the relation between board independence and board leadership is not obvious ( $r=0.021, p=0.419)$. The CEO is the board chair in smaller firms ( $r=-0.233, p<0.001)$, older firms $(r=0.056, p<0.005)$, and less complex firms $(r=-0.139, p<0.001)$. The CEO is also the board chair in less profitable firms ( $r=-0.109, p<0.001$ ), firms with lower MTB ( $r=-0.066, p<0.050)$, firms with higher CEO ownership ( $r=0.060, p<0.050$ ), and firms with more volatility of stock returns $(r=0.081, p<0.005)$.

\subsection{Test results}

Table 2 reports the results of estimating models (1)-(3). The results suggest that board size is positively related to firm size (LnMVE), number of business segments (LnSegments), leverage (LEV), and ownership concentration (Top20 Own) while negatively associated with profitability (ROA), firm age (FirmAge), market-to-book ratio (MTB) and CEO ownership (CEO Own). The coefficients of 0.481, -0.483, and -0.007 on LnMVE, ROA, and CEO Own are significant at $1 \%$, respectively. The coefficients of 0.438 , and -0.029 on $L E V$ and MTB are significant at 5\%, respectively. The coefficients of $0.190,-0.011$ and 0.004 on LnSegments, FirmAge and Top20 Own are significant at 10\% level, respectively. Except for STDRET (coefficient $=-0.597, p=0.127$ ) and FirmAge, results on the other variables are mostly consistent with those in Linck et al. (2008) and consistent with the expectations.

Results in Table 2 suggest that board size decreases with the CEO’s economic power (CEO’s shareholding in the firm). Further, board size increasing in ownership concentration suggests that large blockholders sit on the board to provide management monitoring and thereby, reduce the demand for monitoring from external independent directors. In sum, 
large, complex, more leveraged, and low-growth-option firms are likely to benefit more from monitoring role of the board and the boards are structured accordingly. However, board size is decreasing in firm performance (coefficient of $R O A$ is negative and significant at $1 \%$ ). Growth-option firms are likely to be firms that are more profitable, and these firms are expected to benefit more from advising. These firms keep their board size relatively small because firm monitoring costs are increasing in board size.

The impact of firm age on board size appears to be non-linear, consistent with Linck et al. (2008), but appears to run counter to the Linck et al. results. It is likely that some Australian firms with a long history remain relatively small (requiring smaller boards) while more recent firms are more complex and bigger requiring larger boards. Overall, model (1) explains $43.6 \%$ of the variation in board size, a result which is similar to that of Linck et al. (2008). They achieve an adjusted $R^{2}$ of $44 \%$ with a sample size of 10,636 firm-years (Linck et al., 2008, p. 321).

In Table 2, board independence is increasing in firm size, leverage and director ownership. The coefficients on LnMVE (0.019) and LEV (0.055) are significant at $1 \%$ and 5\% respectively, suggesting that larger firm size and higher debt levels create monitoring demands in the firm making the board more independent. Further, independence is decreasing in market-to-book ratio (MTB significant at 5\%), volatility of security returns (STDRET significant at 1\%), CEO ownership (CEO Own significant at 1\%), and ownership concentration (Top20 Own significant at 5\%). These results suggest that high growth-option firms, high information-asymmetry firms and firms with strong ownership concentration have more independent boards. However, board independence is decreasing in CEO's economic power through share ownership. Further, these results suggest that fewer outsiders (nonexecutive directors) are needed when major shareholders have strong incentives to monitor. Consistent with Linck et al. (2008), board independence is increasing in CEO 
duality (significant at 1\%) but decreasing in CEO's ownership of firm shares (significant at 1\%). That is, CEO duality creates demand for monitoring role of the board but CEO ownership mitigates such demand through the alignment of CEO's interest with that of the shareholders. Overall, these results are consistent with Linck et al. (2008). The results further suggest that, in a low litigation-risk environment like Australia, ownership concentration has a negative effect on board independence.

I define the CEO Duality dummy as one when the CEO is also the board chair. In a smaller sample of 332 firms, ${ }^{9}$ I find that the variable CEO Duality is negatively related to firm size (LnMVE significant at 1\%), and profitability (ROA significant at 5\%). These results are in contrast with Linck et al. (2008) who find that firm size has a positive effect but profitability has no significant effect on CEO duality. However, consistent with Linck et al. (2008), CEO duality is positively related to CEO Age (significant at 5\%) and CEO Tenure (significant at 5\%). Further, ownership concentration (Top20 Own) appears to have a positive but insignificant effect on CEO duality. Overall, board leadership structure appears to be somewhat different in Australia than in the U.S., especially the effect of firm size and profitability on board leadership.

\section{TAKE IN TABLE 2 ABOUT HERE}

To delve more into the influence of firm size on board characteristics, I ranked the full sample of 1,505 firms by $\operatorname{TAS}^{10}$ (smallest to largest) and partitioned it into three equal-sized subsamples: small, medium, and large firms. In each subsample, mean (median) was calculated for the variables representing board structure and firm characteristics. Table 3 (Panel A) reveals that board size and the number of nonexecutive directors in the board both

\footnotetext{
${ }^{9} \mathrm{CEO}$ age and tenure data are mostly unavailable in Australia. These two variables were available only for 448 firms. The combined effect of missing data in these and other variables led to a sample of 332 firms. Linck et al. (2008) face similar data attrition for board leadership analysis. They have 10,636 $(8,840)$ observations for board size (board independence) analysis but only 3,610 observations for board leadership analysis.

${ }^{10}$ Firms were sorted by total assets instead of market capitalisation to maximise the size for each subsample. In the full sample, market capitalisation and total assets are highly positively correlated (Pearson's correlation coefficient $=0.779, p<0.001$ ).
} 
increase consistently with firm size. For example, the mean (median) board size increases from 3.97 (4) members in the small firms subsample to 4.58 (5) in the medium subsample to 6.26 (6) in the large firms subsample. The level of board independence, however, remains similar between small and medium firms (mean around 60\%, median $=67 \%$ ) and rises only for large firms $($ mean $=70 \%$, median $=75 \%)$.

Although the results in Panel A (Table 3) for board size and board independence show a pattern consistent with Linck et al. (2008), board leadership results are in sharp contrast with Linck et al. (2008). In Linck et al.’s (2008) sample, the CEO is also the board chair for $51.4 \%$ of small firms, $56.4 \%$ of medium firms and $71.0 \%$ of large firms. In Australia, it is just the opposite. The proportion of CEOs performing the board chair role declines consistently as the firm size increases - from $48 \%$ in small firms to $32 \%$ in medium firms to $26 \%$ in large firms.

Table 3 (Panel B) also shows that the number of business segments, firm age, leverage and profitability - all increase consistently from small to medium to large firms. The rise of both the mean and the median leverage across firm size means that as firms grow over time and become more mature, their ability to attract and service debts increases. This access to debt capital can fuel a firm's profitability as well. This is reflected in firm performance across the three subsamples. Firm mean (median) $R O A$ increases from $-40 \%$ ($26 \%$ in small firms to $-3 \%$ (1\%) in medium firms to $8 \%(9 \%)$ in large firms. Further, mean $R \& D$ intensity ( $M T B$ ) consistently declines from $2.5 \%$ (3.10) in small firms to $0.2 \%$ (2.44) in large firms. These results are consistent with the notion that smaller firms are more R\&D intensive and have more growth options than larger firms.

\section{TAKE IN TABLE 3 ABOUT HERE}

In terms of ownership structure, across the subsamples, the mean (median) CEO ownership is the highest in medium-sized firms at 9.21\% (1.68\%). On the other hand, 
director ownership is decreasing , and ownership concentration (Top20 Own) is increasing in firm size. This positive association between ownership concentration and firm size is counter-intuitive and inconsistent with Demsetz and Lehn (1985); larger firms with more shares are likely to have more diffused ownership structure. Thus, the phenomenon of ownership concentration increasing in firm size could be idiosyncratic to the Australian capital market. In sum, a clear pattern emerges from Table 3 - board structure varies significantly across firm size.

Untabulated independent samples $t$-tests show statistically significant differences at 1\% level between small- and medium-sized firms, and between medium and large firms with respect to board size and the number of non-executive directors in the board. The difference in mean CEO duality is significant at $1 \%$ between small and medium firms, and at $5 \%$ between medium and large firms. Although the level of board independence is statistically insignificant between small and medium firms, it is significant at $1 \%$ between medium and large firms.

\subsection{Further analysis and robustness checks}

This section reports results of additional tests on board structure. These tests comprise an examination of board structure across firm size, leverage levels and ownership concentration.

\subsubsection{An alternative proxy for firm size}

In untabulated tests, replacing LnMVE in all the models by the natural logarithm of total assets (LnAssets) as an alternative proxy for firm size produces broadly consistent results. In particular, consistent with the results in Table 2, board independence appears to decrease in ownership concentration (significant at 5\%), and CEO duality increases in ownership concentration (significant at 10\%). In board size results, the coefficient on ownership concentration is positive as in Table 2 but statistically insignificant. 


\subsubsection{Determinants of board structure for small, medium, and large firms}

Linck et al. (2008) argue that the determinants of board structure vary across firm size. Following this line of argument, model (1) is re-estimated on the three firm-size-based subsamples. Untabulated results suggest that, in the small firm subsample, board size decreases with firm age (coefficient significant at 5\%) but the relationship is non-linear. Board size is decreasing also in firm leverage (significant at 5\%) and market-to-book ratio (significant at 10\%). In the medium-firms subsample, board size increases with firm age (significant at 5\%) at a decreasing rate, which is consistent with Linck et al. (2008). In the large firms subsample, board size is increasing in firm profitability (significant at 10\%), number of business segments (significant at 1\%), market-to-book ratio (significant at 5\%) and ownership concentration (Top20 Own significant at 5\%) while decreasing in volatility of monthly security returns (significant at 1\%), and CEO ownership (significant at 1\%).

The same procedure was followed for board independence and board leadership. In the small firms subsample, board independence is increasing in firm leverage (significant at $1 \%$ ) while decreasing in the number of business segments (significant at $10 \%$ ), volatility of monthly security returns (significant at 5\%) and CEO ownership (significant at 10\%). In the medium size firms, board independence is increasing in director ownership (significant at 1\%) while decreasing in volatility of security returns (significant at 5\%), CEO ownership (significant at 5\%) and ownership concentration (significant at 10\%). Similar results were obtained for the large firms subsample.

Analysis of board leadership on the three subsamples suggests that, in small firms, CEO duality is increasing in ownership concentration and CEO tenure (both significant at $10 \%$ ) and decreasing in firm profitability (significant at 5\%). In the medium firms, CEO duality is increasing in CEO age and decreasing in market-to-book ratio (both significant at 
5\%). In large firms, CEO duality is increasing in CEO age (significant at 10\%). Overall, board structure appears to vary significantly across firm size.

\subsubsection{Leverage and board structure}

The determinants of board structure may vary across different levels of leverage. To investigate this issue further, I ranked the full sample on the leverage ratio (lowest to highest) and categorised it into three equal-sized subsamples: low, moderate, and high leverage firms. The results of OLS regressions on these subsamples are reported in Table 4: Panel A (board size) and Panel B (board independence). As Panel A shows, regardless of leverage level, board size is increasing in firm size (all the coefficients significant at 1\%). On the other hand, in low-leveraged firms, board size is decreasing in firm profitability (significant at 10\%), market-to-book ratio (significant at 5\%) and CEO ownership (significant at 10\%). In medium-leveraged firms, only firm size ( $L n M V E)$ is statistically significant as a determinant

of board size. In high-leveraged firms, board size is decreasing in director ownership (significant at 10\%). In sum, monitoring benefits from large boards decrease as performance improves in the presence of low leverage, but when leverage is high, monitoring benefits are not conditional on firm performance.

In Panel B (Table 4), the only variable significant in low-leveraged firms is CEO duality (CEO Chair) which positively affects board independence (significant at 5\%). In the moderate and high-leveraged firms, board independence is increasing in firm size (significant at $1 \%$ in both), increasing in director ownership (significant at $1 \%$ for moderate leverage firms; significant at 5\% for high-leveraged firms) and decreasing in volatility of securities returns (significant at $5 \%$ in moderate-leveraged firms and at $1 \%$ in high-leveraged firms. Further, board independence is increasing in firm profitability in high-leveraged firms (significant at 1\%). Further, board independence increases with performance in only highleveraged firms (significant at 1\%). It implies that benefits of outside monitoring increases as 
performance increases in high-leveraged firms. Thus, debt is an alternative mechanism for outside monitoring to control private benefits available to managers. ${ }^{11}$

In relation to board leadership, as Panel $\mathrm{C}$ of Table 4 suggests, CEO duality is decreasing in firm size across all leverage levels (significant at 5\% for low-leveraged firms, at $1 \%$ in both moderate- and high-leveraged firms). In low- and moderate-leveraged firms, CEO duality is increasing in firm age (significant at $1 \%$ and $5 \%$, respectively) but not related to firm age in high-leveraged firms. On the other hand, in both low- and high-leveraged firms, CEO duality is decreasing in the number of business segments (significant at $5 \%$ in both) but not related to the number of business segments in moderate-leveraged firms. Thus, determinants of board leadership vary to some extent across leverage levels.

\section{TAKE IN TABLE 4 ABOUT HERE}

\subsubsection{Ownership concentration and board structure}

As previously discussed, ownership concentration is high in Australia, and it may play a significant role in corporate governance. In particular, Durnev and Kim (2005) provide evidence that corporate governance improves with ownership concentration. Following this line of argument, further analysis is undertaken to examine the determinants of board structure across ownership concentration levels.

Panel A of Table 5 reports descriptive statistics on board size, board independence and CEO duality for each quintile after the sample is sorted by Top20 ownership concentration in ascending order (lowest concentration to highest). Except for the fifth quintile, the mean (median) board size increases monotonically with ownership concentration from 4.6 (4.0) members in the first quintile to 5.4 (5.0) in the fourth quintile. In the fifth quintile, mean board size drops to five members while the median stays at five. Overall, as ownership concentration increases, large blockholders sit in boards making the boards larger. Except

\footnotetext{
${ }^{11}$ Assuming private benefits available to managers are an increasing function of firm performance.
} 
for the fourth quintile, the mean level of board independence decreases monotonically with ownership concentration from $64.4 \%$ in the first quintile to $61.9 \%$ in the fifth quintile. That is, the demand for external monitoring decreases with ownership concentration. These observations are consistent with the predictions of Durnev and Kim (2005). The median level of board independence, however, remains the same at $66.7 \%$ for all quintiles. The incidence of CEO duality is the highest in the $2^{\text {nd }}$ quintile (at 38\%) followed by the $5^{\text {th }}$ quintile (37\%) while it is lowest in the $4^{\text {th }}$ quintile (31\%). Overall, the results in Panel A suggest that board leadership is far more a complex phenomenon than would be perceived from examining a single firm characteristic. Nonetheless, ownership concentration appears to have some influence on board composition.

To investigate whether the determinants of board structure vary across ownership concentration levels, three subsamples (low, moderate, and high ownership concentration) are created following the same procedure as in sections 4.2 and 4.3.2. The results of estimating models (1)-(3) on these subsamples are reported in Panels B through D in Table 5. As Panel B suggests, board size is increasing in firm size (LnMVE) across all the three subsamples (coefficients significant at 1\%). In the moderate ownership concentration firms, board size increases with the number of business segments and $R \& D$ intensity (both significant at $10 \%$ ) but decreases with firm age (significant at 10\%). On the other hand, in high ownership-concentration firms, board size is increasing in leverage (significant at 1\%) and decreasing in CEO ownership (significant at 5\%). Panel C results suggest that leverage and ownership concentration have some substitutive effects on board independence. In the moderate-concentration subsample, board independence is increasing in leverage (significant at $1 \%$ level) whereas it is decreasing in leverage (significant at $5 \%$ level) in high concentration firms. Board independence also increases with CEO duality (significant at 5\%) in low ownership concentration firms but not in other subsamples. Further, in the moderate 
ownership concentration firms, board independence is increasing in director ownership (significant at $1 \%$ ) while decreasing in $R \& D$ intensity (significant at $10 \%$ ) and volatility of security returns (significant at 1\%). These results are consistent with the notion that monitoring benefits by outsiders increase (via more independent boards) with the CEO's bargaining power in the board when insiders' incentives to monitor the management is not strong (i.e., ownership concentration is not high). In high-ownership-concentration firms, board independence is decreasing in market-to-book ratio (significant at 5\%) and CEO ownership (significant at $1 \%$ ).

The results in Panel D of Table 5 suggest that regardless of ownership concentration levels, CEO duality decreases with firm size. These results are in sharp contrast with Linck et al. (2008). Because large firms have greater demands for outside monitoring, separation of the CEO role from the board chair reduces the CEO's bargaining power and is conducive to greater outside monitoring. In medium ownership-concentration firms, CEO duality decreases with profitability (significant at 10\%) and increases with firm age (significant at 10\%). In high-ownership concentration firms, CEO duality is decreasing in the number of business segments (significant at 1\%). Clearly, the determinants of board leadership vary significantly across ownership concentration levels.

TAKE IN TABLE 5 ABOUT HERE

\section{Summary and conclusion}

Investigating what determines board of directors structure is fundamental to understanding the role of corporate governance in firm behaviour. However, there is only limited evidence on this issue and bulk of the extant literature on board structure is focused on the U.S. setting. Because of significant differences in the institutional environments between Australia and the U.S. in terms of corporate legal environment (litigation risks), ownership concentration, firm size and labour market conditions, findings on board structure 
in the U.S. cannot be entirely generalised to Australia. Unlike in the U.S. setting where litigation risk is high and ownership concentration is low, the Australian setting can provide insight into board structure in a low-litigation-risk and high-ownership-concentration environment.

This paper investigates the cross-sectional determinants of board structure in a large, hand-collected dataset of over 1,000 Australian publicly-traded firms in 2006. The sample includes firms of all sizes, performance, industries, and ages. Thus, the results are more generalisable than is possible with more restrictive, context-specific samples.

Multivariate analyses suggest that firm size is the single best predictor of board structure. Board size and board independence are increasing in firm size while CEO duality (i.e., the CEO is also the board chair) is decreasing in firm size. Among the other determinants of board size, board size is increasing in the number of business segments, leverage, and ownership concentration while decreasing in profitability, firm age, marketto-book ratio and CEO ownership. Board independence is increasing in firm size, leverage, CEO duality and director ownership while decreasing in market-to-book ratio, volatility of stock returns, CEO ownership and ownership concentration. Furthermore, CEOs are likely to be board chairs in smaller firms, in less-profitable firms, when CEOs are older and when CEOs have longer tenure.

Overall, the results in this study are consistent with the notion that firms choose board structures based on the benefits and costs of advising and monitoring. While the results are generally consistent with Linck et al. (2008), there are notable differences as well. Linck et al. (2008) find significant differences in the determinants of board structure between large and small firms. As Australia is a high-ownership-concentration country, variation in the determinants of board structure appears to be pronounced in ownership concentration levels. If high litigation risk against directors (as in the U.S.) has a 
monitoring role in corporate governance, ownership concentration appears to offer an alternative governance mechanism in low-litigation-risk countries such as Australia. The determinants also appear to differ significantly across leverage levels and to some extent across firm size. There is also evidence that ownership concentration and leverage have some substitutive effect in determining the board structure.

Another important difference between Australia and the U.S. is that the board chair and the CEO roles are combined in large firms in the U.S., when the CEO is aged, or has long tenure (Linck et al., 2008) whereas, in Australia, the two roles are combined in smaller firms, less-profitable firms, when the CEO is older or has longer tenure. In the U.S., CEO duality is increasing in firm size whereas in Australia it is decreasing in firm size. In fact, the board is led by the CEO in around 51\% of the small firms, $56 \%$ of the medium firms and $71 \%$ of the large firms in the U.S. (Linck et al., 2008, p. 316). In contrast, the board is led by the CEO in only $48 \%$ of the small firms, $32 \%$ of the medium firms and $26 \%$ of the large firms in Australia. Moreover, in the U.S., successful CEOs are awarded board leadership as part of promotion and succession process (Brickley et al., 1997). Hence, the differences in governance structure between the U.S. and Australia could be due to differences in institutional environments. It is likely that, in the U.S. corporate world, where wealth creation and profitability are championed, shareholders value advising role of the board more than they value the monitoring role. On the contrary, in Australia with a highly unionized society and a working class mentality, investors are likely to be always suspicious of the corporate insiders. In this environment, monitoring role of the board may be valued more by shareholders than advising role. The likely outcomes of this are boards that are relatively more independent, larger, and where the board leadership is separate from the CEO. 


\section{References}

Adams, R., Ferreira, D., 2007. A theory of friendly boards. Journal of Finance 62, 217-250.

Adie, J., Sonder, L., 2004. Submission to the senate select committee on chapter eighteen (labour) of the draft Australia-United State of America free trade agreement (available at http:/www.aph.gov.au/senate_freetrade/submissions/sub481.pdf; accessed on 7 April 2010), 1-8.

Aguilera, R., Jackson, J., 2003. The cross-national diversity of corporate governance: Dimensions and determinants, The Academy of Management Review 28, 447-465.

ASX Corporate Governance Council, 2003. Principles of Good Governance and Best Practice Recommendations. ASX: Sydney.

Bhagat, S., Bolton, B., 2008. Corporate governance and firm performance. Journal of Corporate Finance 14, 257-273.

Boone, A., Field, L., Karpoff, J., Raheja, C., 2007. The determinants of corporate board size and composition: An empirical analysis. Journal of Financial Economics 85, 66-101.

Booth, J., Deli, D., 1999. On executives of financial institutions as outside directors. Journal of Corporate Finance 5, 227-250.

Bowen, R., Rajgopal, S., Venkatachalam, M., 2008. Accounting discretion, corporate governance and firm performance. Contemporary Accounting Research 25, 351-405.

Brown, L. D., Caylor, M. L., 2009. Corporate governance and firm operating performance. Review of Quantitative Finance and Accounting 32, 129-144.

Brickley, J., Coles, J., Jarrell, G., 1997. Leadership structure: Separating the CEO and chairman of the board, Journal of Corporate Finance 3, 189-220.

Bushman, R., Chen, Q., Engel E., Smith, A., 2004. Financial accounting information, organization complexity, and corporate governance. Journal of Accounting and Economics 37, 167-201. 
Cheffins, B., Black, B., 2006. Outside director liability across countries. Texas Law Review 84, 1385-1480.

Coles, J., Daniel N., Naveen, L., 2008. Boards: Does one size fit all?. Journal of Financial Economics 87, 329-356.

Core, J., Holthausen, R., Larcker, D., 1999. Corporate governance, chief executive officer compensation, and firm performance, Journal of Financial Economics 51, 371-406.

Denis, K., McConnell, J., 2003. International corporate governance. Journal of Financial and Quantitative Analysis 38, 1-36.

Demsetz, H., Lehn, K., 1985. The structure of corporate ownership: Causes and consequences. The Journal of Political Economy 93, 1155-1177.

Demsetz, H., Villalonga, B., 2001. Ownership structure and corporate performance. Journal of Corporate Finance 7, 209-233.

Demirag, I., Solomon, J., 2003. Developments in international corporate governance and the impact of recent events. Corporate Governance: An International Review 11, 1-7.

Durnev, A., Kim, E., 2005. To steal or not to steal: firm attributes, legal environment, and valuation. The Journal of Finance 60, 1461-1493.

Fama, E., Jensen, M., 1983. Separation of ownership and control. Journal of Law and Economics 26, 301-325.

Gaver, J., Gaver, K., 1993. Additional evidence on the association between the investment opportunity set and corporate financing, dividend, and compensation policies. Journal of Financial Economics 16, 125-160.

Gillian, S., Starks, L., 2003. Corporate governance, corporate ownership, and the role of institutional investors: A global perspective. Journal of Applied Finance 13, 4-22.

Gompers, P., Isshii J., Metrick, A., 2003. Corporate governance and equity prices. Quarterly Journal of Economics 118, 107-155. 
Hermalin, B., Weisbach, M., 1998. Endogenously chosen boards of directors and their monitoring of the CEO. American Economic Review 88, 96-118.

Holderness, C., 2003. A survey of blockholders and corporate control. FRBNY Economic Policy Review, April, 51-64 (http://ftp.ny.frb.org/research/epr/03v09n1/0304hold.pdf; last accessed on 22 May 2012).

Holstrom, B. Kaplan, S., 2001. Corporate governance and merger activity in the United States: Making sense of the 1980s and 1990s. The Journal of Economic Perspectives $15,121-144$.

Hutchinson, M., Gul, F.A., 2004. Investment opportunity set, corporate governance practices and firm performance. Journal of Corporate Finance 10, 595-614.

Jensen, M., 1986. Agency costs of free cash flow, corporate finance, and takeovers. American Economic Review 76, 323-329.

Jensen, M., 1993. The modern industrial revolution, exit, and the failure of internal control systems. Journal of Finance 48, 831-880.

Kang, J., Shivdasani, A., 1995. Firm performance, corporate governance and top executive turnover in Japan. Journal of Financial Economics 38, 29-58.

La Porta, R., Lopez-de-Silanes, F., Shleifer A., Vishny, R., 1998. Law and finance. Journal of Political Economy 106, 1113-1155.

Lemmon, M. Lins, K., 2003. Ownership structure, corporate governance and firm value: Evidence from the East Asian financial crisis. The Journal of Finance 58, 1445-1468.

Lim, S., Matolcsy Z., Chow, D., 2007. The association between board composition and different types of voluntary disclosure. European Accounting Review 16, 555-583.

Linck, J.S., Netter, J.M., Yang, T., 2008. The determinants of board structure. Journal of Financial Economics 87, 308-328. 
Lloyd, P., 2008. 100 years of tariff protection in Australia. Australian Economic History Review 48, 99-145.

Maug, E., 1997. Board of directors and capital structure: Alternative forms of corporate restructuring. Journal of Corporate Finance 3, 113-139.

Nagelkerke, N.J., 1991. A note on the general definition of the coefficient of determination. Biometrika 78, 691-692.

Raheja, C., 2005. Determinants of board size and composition: A theory of corporate boards. Journal of Financial and Quantitative Analysis 40, 283-306.

Rawling, M., 2006. Australian trade unions as shareholder activists: The rocky path towards corporate democracy. Sydney Law Review 28, 227-258.

Shekhar, C., Stapledon, G., 2007. Governance structures of initial public offerings in Australia. Corporate Governance: An International Review 15, 1177-1189.

Smith, C., Watts, R., 1992. The investment opportunity set and corporate financing, dividend, and compensation policies. Journal of Financial Economics 32, 263-292.

Thai, L., 2002. How popular are statutory derivative actions in Australia? Comparisons with the United States, Canada and New Zealand. Australian Business Law Review 30, 118136. 
Table 1

Descriptive statistics: firm characteristics and board structure

\begin{tabular}{|c|c|c|c|c|c|c|c|}
\hline & $N$ & Mean & Std. Deviation & $25^{\text {th }}$ Percentile & $50^{\text {th }}$ Percentile & $75^{\text {th }}$ Percentile & $90^{\text {th }}$ Percentile \\
\hline \multicolumn{8}{|l|}{ Firm Characteristics } \\
\hline MVE (A\$ million) & 1150 & $\$ 984.6$ & $\$ 7,806.7$ & 13.6 & $\$ 47.0$ & 209.3 & $1,027.3$ \\
\hline Total Assets (A \$ million) & 1462 & 763.9 & 4688.3 & 7.7 & 28.58 & 166.1 & 1052.3 \\
\hline$L E V(\%)$ & 1462 & 34.9 & 27.9 & 9.2 & 29.6 & 55.1 & 75.4 \\
\hline$R O A(\%)$ & 1462 & -12.90 & 34.74 & -21.83 & -1.97 & 9.37 & 17.67 \\
\hline FirmAge (in years) & 1462 & 12.22 & 12.90 & 3.08 & 7.67 & 19.18 & 25.52 \\
\hline Business Segments & 1462 & 1.55 & 1.02 & 1.00 & 1.00 & 2.00 & 3.00 \\
\hline Market-to-Book ratio & 1400 & 2.14 & 3.18 & 0.50 & 1.24 & 2.59 & 4.87 \\
\hline$R \& D$ & 1462 & 0.01 & 0.06 & 0.00 & 0.00 & 0.00 & 0.00 \\
\hline STDRET & 1414 & 0.17 & 0.13 & 0.08 & 0.14 & 0.21 & 0.33 \\
\hline Free Cashflow & 1462 & 0.02 & 6.62 & -0.34 & -0.12 & 0.02 & 0.12 \\
\hline \multicolumn{8}{|l|}{ Ownership Characteristics } \\
\hline CEO Own (\%) & 1094 & 7.41 & 15.96 & 0.02 & 0.90 & 6.29 & 23.40 \\
\hline Director Own (\%) & 1096 & 7.09 & 15.06 & 0.04 & 0.80 & 6.78 & 21.53 \\
\hline Top20 Own (\%) & 1462 & 63.68 & 18.55 & 50.94 & 64.85 & 78.16 & 87.39 \\
\hline \multicolumn{8}{|l|}{ Governance Characteristics } \\
\hline Board Size & 1462 & 4.92 & 1.76 & 4.00 & 5.00 & 6.00 & 7.00 \\
\hline Nonexecutive Directors & 1462 & 3.22 & 1.71 & 2.00 & 3.00 & 4.00 & 5.00 \\
\hline Board Independence (\%) & 1462 & 0.64 & 0.20 & 0.50 & 0.67 & 0.80 & 0.86 \\
\hline CEO Duality & 1462 & 0.35 & 0.48 & 0.00 & 0.00 & 1.00 & 1.00 \\
\hline \multicolumn{8}{|l|}{ CEO Characteristics } \\
\hline CEO Age (in years) & 448 & 56.22 & 7.49 & 51.00 & 57.00 & 61.00 & 65.00 \\
\hline CEO Tenure (in years) & 448 & 5.29 & 5.72 & 1.00 & 3.00 & 7.00 & 14.00 \\
\hline
\end{tabular}

Variable definition: $M V E=$ Market value of equity; Total Assets = Book value of total assets at the end of $2006 ; L E V=$ Leverage ratio $=$ Total Liabilities divided by Total Assets; $R O A=$ Earnings Before Interest and Taxes divided by Total Assets; FirmAge = The number of years the firm has been listed at the Australian Securities Exchange till the end of 2006 fiscal-year; Business Segments = The number of business segments in the firm; Market-to-Book ratio = Market-to-book ratio of equity; $R \& D=\mathrm{R} \& D$ expenditures $/$ Total Assets; STDRET = Standard deviation of monthly stock returns over the preceding fiscal year; Free Cashflow = Operating cash flow less net capital investments during the year scaled by Total Assets; CEO Own = The percentage of firm shares owned by the CEO; Director Own = The percentage of firm shares owned by the directors other than the CEO; Top20 Own = The percentage of firm shares owned by the Top 20 shareholders; Board Size = The number of members in the board of directors; Nonexecutive Directors = The number of nonexecutive directors in the board; Board Independence $=$ The proportion of nonexecutive directors in the board.; $C E O$ Duality $=$ Dummy variable which takes a value of one when the CEO is also the board chair; $C E O$ Age = CEO's age measured in years; CEO Tenure = The number of years the CEO held the current position in the firm. 
Table 2

Determinants of board structure

This table reports results of regressing board size, board independence, and board leadership on firm characteristics: models (1) - (3). Models (1) and (2) were estimated via OLS regressions for board size and board independence, respectively. Binary logistic regression was estimated using model (3) for board leadership.

\begin{tabular}{|c|c|c|c|c|c|c|}
\hline \multirow[t]{2}{*}{ Variable } & \multicolumn{2}{|c|}{ Board Size } & \multicolumn{2}{|c|}{ Board Independence } & \multicolumn{2}{|c|}{ CEO Duality } \\
\hline & Prediction & $\begin{array}{c}\text { Coefficient } \\
\text { (p-value) }\end{array}$ & Prediction & $\begin{array}{c}\text { Coefficient } \\
\text { (p-value) }\end{array}$ & Prediction & $\begin{array}{c}\text { Coefficient } \\
\text { ( } p \text {-value) }\end{array}$ \\
\hline LnMVE & + & $0.481(0.000)^{\mathrm{a}}$ & + & $0.019(0.000)^{\mathrm{a}}$ & - & $-0.397(0.000)^{\mathrm{a}}$ \\
\hline$R O A$ & - & $-0.483(0.000)^{\mathrm{a}}$ & - & $-0.022(0.409)$ & + & $-1.345(0.019)^{b}$ \\
\hline LnSegments & + & $0.190(0.052)^{\mathrm{c}}$ & + & $-0.015(0.282)$ & & \\
\hline$L E V$ & + & $0.438(0.016)^{\mathrm{b}}$ & + & $0.055(0.037)^{\mathrm{b}}$ & & \\
\hline FirmAge & + & $-0.011(0.066)^{\mathrm{C}}$ & + & $-0.001(0.450)$ & & \\
\hline FirmAge $^{2}$ & - & $0.000(0.079)^{\mathrm{c}}$ & - & $0.000(0.139)$ & & \\
\hline MTB & - & $-0.029(0.024)^{\mathrm{b}}$ & - & $-0.004(0.045)^{\mathrm{b}}$ & + & $0.053(0.213)$ \\
\hline$R \& D$ & - & $0.537(0.396)$ & - & $-0.050(0.587)$ & + & $-0.571(0.760)$ \\
\hline STDRET & - & $-0.597(0.127)$ & - & $-0.207(0.000)^{\mathrm{a}}$ & + & $-1.132(0.445)$ \\
\hline CEO Own & - & $-0.007(0.007)^{\mathrm{a}}$ & - & $-0.001(0.001)^{\mathrm{a}}$ & & \\
\hline Director Own & + & $0.000(0.749)$ & + & $0.000(0.011)^{\mathrm{b}}$ & & \\
\hline Top20 Own & + & $0.004(0.083)^{\mathrm{C}}$ & - & $-0.001(0.041)^{\mathrm{b}}$ & + & $0.007(0.447)$ \\
\hline Free Cashflow & & & + & $0.002(0.927)$ & & \\
\hline CEO Chair & & & + & $0.036(0.007)^{\mathrm{a}}$ & & \\
\hline CEO Age & & & & & + & $0.057(0.011)^{b}$ \\
\hline CEO Tenure & & & & & + & $0.055(0.025)^{\mathrm{b}}$ \\
\hline Intercept & ? & $-4.041(0.000)^{\mathrm{a}}$ & ? & $0.358(0.000)^{\mathrm{a}}$ & ? & $1.460(0.511)$ \\
\hline Industry dummie & & Yes & & Yes & & Yes \\
\hline$N$ & & 1,029 & & 1,021 & & 332 \\
\hline Model F-statisti & ( $p$-value) & $40.735(0.000)$ & & $5.728(0.000)$ & & \\
\hline Adj. $R^{2}$ & & 0.436 & & 0.096 & & \\
\hline Durbin-Watson & atistic & 2.019 & & 1.943 & & \\
\hline Nagelkerke (199 & $R^{2}$ & & & & & 0.238 \\
\hline $\begin{array}{l}\text { Hosmer-Lemesh } \\
\text { ( } p \text {-value) }\end{array}$ & W test statis & $\chi^{2}$ for 8 d.f. & & & & $7.580(0.475)$ \\
\hline
\end{tabular}

Variable definition: Board Size $=$ The number of members in the board of directors; Board Independence $=$ The proportion of nonexecutive directors in the board; CEO Duality (CEO Chair) = Dummy variable which takes a value of one when the CEO is also the board chair; $L n M V E=$ Natural logarithm of market value of equity; Total Assets = Book value of total assets at the end of 2006; $L E V=$ Leverage ratio = Total Liabilities divided by Total Assets; $R O A=$ Earnings Before Interest and Taxes divided by Total Assets; FirmAge $=$ The number of years the firm has been listed at the Australian Securities Exchange till the end of 2006 fiscal-year; LnSegments = The number of business segments in the firm; Market-to-Book ratio = Market-to-book ratio of equity; $R \& D=\mathrm{R} \& D$ expenditures $/$ Total Assets; STDRET $=$ Standard deviation of monthly stock returns over the preceding fiscal year; Free Cashflow = Operating cash flow less net capital investments during the year scaled by Total Assets; CEO Own = The percentage of firm shares owned by the CEO; Director Own = The percentage of firm shares owned by the directors other than the CEO; Top20 Own = The percentage of firm shares owned by the Top 20 shareholders; CEO Age = CEO's age measured in years; $C E O$ Tenure = The number of years the CEO held the current position in the firm; Industry Dummies = Dummy variables to capture the differences in board structure due to industry characteristics; Industry classification is based on Standard \& Poor's two-digit Global Industry Classification Scheme (GICS). 
Table 3

Board and firm characteristics across three categories of firm size

This table reports descriptive statistics on board and firm characteristics for three subsamples based on firm size. The full sample was ranked by total assets (smallest to largest) and partitioned into small (the smallest one-third firms), medium (the middle one-third) and large (the largest one-third of the sample firms). Then mean(median) was calculated for each variable of interest.

Panel A: Board characteristics

\begin{tabular}{|lccc|}
\hline Variables & $\begin{array}{l}\text { Small }(N=493) \\
\text { Mean (Median) }\end{array}$ & $\begin{array}{l}\text { Medium }(N=497) \\
\text { Mean (Median) }\end{array}$ & $\begin{array}{l}\text { Large }(N=499) \\
\text { Mean (Median) }\end{array}$ \\
\hline \hline Board Size & $3.97(4)$ & $4.58(5)$ & $6.26(6)$ \\
Non-executive Directors & $2.42(2)$ & $2.83(3)$ & $4.45(4)$ \\
Board Independence & $0.60(0.67)$ & $0.61(0.67)$ & $0.70(0.75)$ \\
CEO Duality & $0.48(0.00)$ & $0.32(0.00)$ & $0.26(0.00)$ \\
\hline
\end{tabular}

Panel B: Firm characteristics

\begin{tabular}{|lccc|}
\hline Variables & Small $(N=320)$ & Medium $(N=357)$ & $\begin{array}{c}\text { Large }(N=373) \\
\text { Mean (Median) } \\
\text { Mean (Median) }\end{array}$ \\
\hline \hline Segments & $1.15(1.00)$ & $1.41(1.00)$ & $2.13(2.00)$ \\
FirmAge & $10.05(5.83)$ & $11.52(7.42)$ & $14.96(10.09)$ \\
Leverage (ratio) & $0.21(0.09)$ & $0.31(0.27)$ & $0.49(0.51)$ \\
ROA (ratio) & $-0.40(-0.26)$ & $-0.03(0.01))$ & $0.08(0.09)$ \\
R\&D & $0.025(0.000)$ & $0.016(0.000)$ & $0.002(0.000)$ \\
Market-to-Book ratio & $3.10(1.64)$ & $2.60(1.65)$ & $2.44(1.67)$ \\
CEO Own & $7.10(1.78)$ & $9.21(1.68)$ & $6.16(0.26)$ \\
Director Own & $16.08(1.72)$ & $8.53(1.32)$ & $7.78(0.23)$ \\
Top20 Own & $59.0(59.0)$ & $66.0(66.0)$ & $67.0(70.0)$ \\
\hline
\end{tabular}

Variable definition: Board Size $=$ The number of members in the board of directors; Nonexecutive Directors $=$ The number of nonexecutive directors in the board; Board Independence = The proportion of nonexecutive directors in the board; $C E O$ Duality = Dummy variable which takes a value of one when the CEO is also the board chair; MVE = Market value of equity; Total Assets = Book value of total assets at the end of 2006; LEV = Leverage ratio = Total Liabilities divided by Total Assets; $R O A=$ Earnings Before Interest and Taxes divided by Total Assets; FirmAge $=$ The number of years the firm has been listed at the Australian Securities Exchange till the end of 2006 fiscal-year; Business Segments = The number of business segments in the firm; Market-to-Book ratio = Market-to-book ratio of equity; $R \& D=\mathrm{R} \& \mathrm{D}$ expenditures /Total Assets; $S T D R E T=$ Standard deviation of monthly stock returns over the preceding fiscal year; Free Cashflow = Operating cash flow less net capital investments during the year scaled by Total Assets; CEO Own = The percentage of firm shares owned by the CEO; Director Own = The percentage of firm shares owned by the directors other than the CEO; Top20 Own $=$ The percentage of firm shares owned by the Top 20 shareholders. 
Table 4

Leverage and board structure

This table reports the results of estimating model (1) -(3) on the three subsamples of low, moderate and high leverage firms. The full sample was ranked by leverage (lowest to highest) and partitioned into low (the first one-third firms with lowest leverage), moderate (the middle one-third firms) and high (the bottom one-third firms with highest leverage). Models (1) and (2) were estimated via OLS regressions for board size and board independence, respectively. Model (3) was estimated via binary logistic regression for board leadership.

Panel A: Board Size

\begin{tabular}{|c|c|c|c|}
\hline & $\begin{array}{l}\text { Low Leverage Firms } \\
\text { Coeff ( } p \text {-value) }\end{array}$ & $\begin{array}{c}\text { Moderate Leverage Firms } \\
\text { Coeff ( } p \text {-value) }\end{array}$ & $\begin{array}{l}\text { High Leverage Firms } \\
\text { Coeff ( } p \text {-value) }\end{array}$ \\
\hline LnMVE & $0.367(0.000)^{\mathrm{a}}$ & $0.454(0.000)^{\mathrm{a}}$ & $0.528(0.000)^{\mathrm{a}}$ \\
\hline$R O A$ & $-0.392(0.098)^{c}$ & $-0.050(0.850)$ & $0.308(0.391)$ \\
\hline LnSegments & $-0.031(0.895)$ & $0.133(0.410)$ & $0.230(0.169)$ \\
\hline FirmAge & $-0.001(0.891)$ & $-0.008(0.468)$ & $-0.011(0.370)$ \\
\hline FirmAge $^{2}$ & $0.000(0.963)$ & $-0.000(0.951)$ & $0.000(0.125)$ \\
\hline MTB & $-0.052(0.011)^{b}$ & $-0.033(0.238)$ & $-0.004(0.859)$ \\
\hline$R \& D$ & $1.468(0.165)$ & $0.790(0.422)$ & $-0.528(0.700)$ \\
\hline STDRET & $-0.603(0.242)$ & $-0.620(0.344)$ & $0.031(0.976)$ \\
\hline CEO Own & $-0.009(0.092)^{c}$ & $-0.002(0.632)$ & $-0.012(0.050)^{b}$ \\
\hline Director Own & $0.002(0.708)$ & $0.005(0.157$ & $0.000(0.745)$ \\
\hline Top20 Own & $0.004(0.290)$ & $0.000(0.985)$ & $0.008(0.123)$ \\
\hline Intercept & $-2.200(0.000)^{\mathrm{a}}$ & $-3.322(0.000)^{\mathrm{a}}$ & -4.862 \\
\hline Industry dummies & Yes & Yes & Yes \\
\hline$N$ & 349 & 344 & 347 \\
\hline $\begin{array}{l}\text { Model F-statistic } \\
\text { ( } p \text {-value) }\end{array}$ & $5.636(0.000)$ & $10.660(0.000)$ & $14.565(0.000)^{\mathrm{a}}$ \\
\hline Adj. $R^{2}$ & 0.210 & 0.360 & 0.447 \\
\hline Durbin-Watson statistic & 1.952 & 1.985 & 2.082 \\
\hline
\end{tabular}

Panel B: Board Independence

\begin{tabular}{|c|c|c|c|}
\hline & $\begin{array}{l}\text { Low Leverage Firms } \\
\text { Coeff ( } p \text {-value) }\end{array}$ & $\begin{array}{l}\text { Moderate Leverage Firms } \\
\text { Coeff ( } p \text {-value) }\end{array}$ & $\begin{array}{c}\text { High Leverage Firms } \\
\text { Coeff ( } p \text {-value) }\end{array}$ \\
\hline$\overline{L n M V E}$ & $\begin{array}{l}0.000(0.975) \\
\end{array}$ & $0.024(0.000)^{\mathrm{a}}$ & $\begin{array}{ll}0.020(0.001)^{\mathrm{a}} \\
\end{array}$ \\
\hline$R O A$ & $0.013(0.800)$ & $-0.017(0.722)$ & $0.142(0.002)^{\mathrm{a}}$ \\
\hline LnSegments & $0.004(0.930)$ & $-0.029(0.190)$ & $-0.004(0.829)$ \\
\hline FirmAge & $-0.002(0.316)$ & $-0.002(0.152)$ & $0.000(0.847)$ \\
\hline FirmAge $e^{2}$ & $0.000(0.218)$ & $0.000(0.160)$ & $0.000(0.650)$ \\
\hline MTB & $-0.002(0.680)$ & $-0.008(0.044)^{b}$ & $-0.003(0.214)$ \\
\hline$R \& D$ & $-0.028(0.242)$ & $-0.011(0.937)$ & $0.129(0.454)$ \\
\hline STDRET & $-0.125(0.191)$ & $-0.212(0.020)^{b}$ & $-0.342(0.007)^{\mathrm{a}}$ \\
\hline CEO Own & $-0.001(0.336)$ & $-0.001(0.105)$ & $-0.003(0.000)^{\mathrm{a}}$ \\
\hline Director Own & $0.001(0.471)$ & $0.002(0.005)^{\mathrm{a}}$ & $0.001(0.022)^{b}$ \\
\hline Top20 Own & $-0.001(0.155)$ & $0.000(0.762)$ & $-0.001(0.143)$ \\
\hline Free Cashflow & $0.018(0.700)$ & $0.001(0.687)$ & $0.012(0.632)$ \\
\hline CEO Chair & $0.055(0.026)^{b}$ & $0.009(0.969)$ & $0.026(0.295)$ \\
\hline Intercept & $0.668(0.000)^{\mathrm{a}}$ & $0.304(0.016)^{\mathrm{a}}$ & $0.389(0.003)^{\mathrm{a}}$ \\
\hline Industry dummies & Yes & Yes & Yes \\
\hline$N$ & 345 & 342 & 334 \\
\hline $\begin{array}{l}\text { Model F-statistic } \\
\text { ( } p \text {-value) }\end{array}$ & $1.463(0.084)$ & $2.505(0.000)$ & $3.545(0.000)$ \\
\hline Adj. $R^{2}$ & 0.029 & 0.088 & 0.144 \\
\hline Durbin-Watson statistic & 2.116 & 2.060 & 1.795 \\
\hline
\end{tabular}

(Table 4 continued on next page.) 
Table 4 (contd.)

Panel C: Board Leadership

\begin{tabular}{|c|c|c|c|}
\hline & $\begin{array}{l}\text { Low Leverage Firms } \\
\text { Coeff ( } p \text {-value) }\end{array}$ & $\begin{array}{c}\text { Moderate Leverage Firms } \\
\text { Coeff ( } p \text {-value) }\end{array}$ & $\begin{array}{c}\text { High Leverage Firms } \\
\text { Coeff ( } p \text {-value) }\end{array}$ \\
\hline LnMVE & $-0.222(0.029) \mathrm{b}$ & $-0.365(0.000) \mathrm{a}$ & $-0.264(0.001) \mathrm{a}$ \\
\hline$R O A$ & $0.288(0.534)$ & $-0.230(0.587)$ & $-0.679(0.187)$ \\
\hline LnSegments & $-1.221(0.018) b$ & $-0.170(0.549)$ & $-0.573(0.028) b$ \\
\hline FirmAge & $0.057(0.005) \mathrm{a}$ & $0.040(0.045) \mathrm{b}$ & $-0.010(0.618)$ \\
\hline FirmAge $^{2}$ & $0.000(0.777)$ & $0.000(0.750)$ & $0.000(0.485)$ \\
\hline MTB & $0.028(0.485)$ & $0.042(0.343)$ & $-0.038(0.303)$ \\
\hline$R \& D$ & $-41.477(0.092) \mathrm{c}$ & $-0.598(0.726)$ & $1.974(0.381)$ \\
\hline STDRET & $0.858(0.384)$ & $-0.054(0.960)$ & $-0.321(0.819)$ \\
\hline Intercept & 2.349 (0.182). & $5.067(0.001) \mathrm{a}$ & 4.278 (0.008)a \\
\hline Industry dummies & Yes & Yes & Yes \\
\hline$N$ & 368 & 370 & 366 \\
\hline Nagelkerke (1991) $R^{2}$ & 0.217 & 0.207 & 0.199 \\
\hline $\begin{array}{l}\text { Hosmer and Lemeshow test } \\
\text { statistic: } \chi^{2} \text { with } 8 \text { d.f. } \\
\text { ( } p \text {-value) }\end{array}$ & $14.815(0.063)^{\mathrm{C}}$. & $3.172(0.923)$ & $9.525(0.300)$ \\
\hline $\begin{array}{l}\text { Correct classification } \\
\text { percentage by model (naive } \\
\text { prediction) }\end{array}$ & $66.0(61.7)$ & $71.7(65.1)$ & $74.0(72.4)$ \\
\hline
\end{tabular}

${ }^{\mathrm{a}},{ }^{\mathrm{b}}$ and ${ }^{\mathrm{c}}$ denote significance at the $1 \%, 5 \%$, and $10 \%$ levels (two-tailed test).

Variable definition: Board Size $=$ The number of members in the board of directors; Board Independence $=$ The proportion of nonexecutive directors in the board; CEO Duality (CEO Chair) = Dummy variable which takes a value of one when the CEO is also the board chair; $L n M V E=$ Natural logarithm of market value of equity; Total Assets = Book value of total assets at the end of 2006; $L E V=$ Leverage ratio = Total Liabilities divided by Total Assets; $R O A=$ Earnings Before Interest and Taxes divided by Total Assets; FirmAge = The number of years the firm has been listed at the Australian Securities Exchange till the end of 2006 fiscal-year; LnSegments = The number of business segments in the firm; Market-to-Book ratio $=$ Market-to-book ratio of equity; $R \& D=\mathrm{R} \& D$ expenditures $/$ Total Assets; STDRET $=$ Standard deviation of monthly stock returns over the preceding fiscal year; Free Cashflow = Operating cash flow less net capital investments during the year scaled by Total Assets; CEO Own = The percentage of firm shares owned by the CEO; Director Own = The percentage of firm shares owned by the directors other than the CEO; Top20 Own = The percentage of firm shares owned by the Top 20 shareholders; $C E O$ Age = CEO's age measured in years; $C E O$ Tenure = The number of years the CEO held the current position in the firm; Industry Dummies = Dummy variables to capture the differences in board structure due to industry characteristics; Industry classification is based on Standard \& Poor's two-digit Global Industry Classification Scheme (GICS). 
Table 5

Ownership concentration and board structure

This table reports the results of estimating models (1) -(3) on the three subsamples of low, moderate and high ownership concentration (Top20 Ownership percentage) firms. The full sample was ranked by ownership concentration (lowest to highest) and partitioned into low (the first one-third firms with lowest concentration), moderate (the middle one-third firms) and high (the bottom one-third firms with highest leverage). Models (1) and (2) were estimated via OLS regressions for board size and board independence, respectively. Model (3) was estimated via binary logistic regression for board leadership.

Panel A: Descriptive statistics on board composition after sorting firms by ownership concentration

\begin{tabular}{l|ccc}
\hline Quintile & $\begin{array}{c}\text { Board Size } \\
\text { Mean (Median) }\end{array}$ & $\begin{array}{c}\text { Board Independence } \\
\text { Mean (Median) }\end{array}$ & $\begin{array}{c}\text { CEO Duality } \\
\text { Mean (Median) }\end{array}$ \\
\hline 1st & $4.6(4.0)$ & $64.4(66.7) \%$ & $0.34(0.00)$ \\
2nd & $4.7(4.0)$ & $64.3(66.7) \%$ & $0.38(0.00)$ \\
3rd & $4.9(5.0)$ & $62.5(66.7) \%$ & $0.36(0.00)$ \\
4th & $5.4(5.0)$ & $65.6(66.7) \%$ & $0.31(0.00)$ \\
5th & $5.0(5.0)$ & $61.9(66.7) \%$ & $0.37(0.00)$ \\
\hline
\end{tabular}

Panel B: Ownership concentration and board size

\begin{tabular}{|c|c|c|c|}
\hline & $\begin{array}{l}\text { Low Ownership } \\
\text { Concentration } \\
\text { Coeff ( } p \text {-value) }\end{array}$ & $\begin{array}{c}\text { Moderate Ownership } \\
\text { Concentration } \\
\text { Coeff ( } p \text {-value) }\end{array}$ & $\begin{array}{l}\text { High Ownership } \\
\text { Concentration } \\
\text { Coeff ( } p \text {-value) } \\
\end{array}$ \\
\hline LnMVE & $0.458(0.000)^{\mathrm{a}}$ & $0.429(0.000)^{\mathrm{a}}$ & $0.509(0.000)^{\mathrm{a}}$ \\
\hline$R O A$ & $-0.382(0.112)$ & $0.360(0.195)$ & $-0.046(0.895)$ \\
\hline LnSegments & $0.121(0.503)$ & $0.310(0.080)^{\mathrm{c}}$ & $0.027(0.871)$ \\
\hline$L E V$ & $0.468(0.122)$ & $0.109(0.731)$ & $0.934(0.006)^{\mathrm{a}}$ \\
\hline FirmAge & $-0.005(0.662)$ & $-0.018(0.084)^{\mathrm{c}}$ & $-0.001(0.944)$ \\
\hline FirmAge $^{2}$ & $0.000(0.845)$ & $0.000(0.001)^{\mathrm{a}}$ & $0.000(0.298)$ \\
\hline MTB & $-0.024(0.300)$ & $-0.032(0.143)$ & $-0.033(0.167)$ \\
\hline$R \& D$ & $-0.246(0.769)$ & $2.084(0.073)^{\mathrm{C}}$ & $-0.285(0.865)$ \\
\hline STDRET & $-0.622(0.302)$ & $-1.105(0.116)$ & $-0.169(0.830)$ \\
\hline CEO Own & $-0.004(0.393)$ & $-0.003(0.607)$ & $-0.010(0.010)^{b}$ \\
\hline Director Own & $-0.003(0.676)$ & $0.004(0.456)$ & $0.005(0.243)$ \\
\hline Intercept & $-3.571(0.000)$ & $-2.622(0.005)$ & $-4.662(0.000)$ \\
\hline Industry dummies & Yes & Yes & Yes \\
\hline$N$ & 345 & 354 & 330 \\
\hline Model F-static ( $p$-value) & $13.544(0.000)$ & $14.242(0.000)$ & $14.642(0.000)$ \\
\hline Adj. $R^{2}$ & 0.422 & 0.429 & 0.453 \\
\hline Durbin-Watson statistic & 1.908 & 2.008 & 1.937 \\
\hline
\end{tabular}

(Table 5 continues on next page) 
Table 5 (continued)

Panel C: Ownership concentration and board Independence

\begin{tabular}{|c|c|c|c|}
\hline & $\begin{array}{l}\text { Low Ownership } \\
\text { Concentration } \\
\text { Coeff ( } p \text {-value) } \\
\end{array}$ & $\begin{array}{c}\text { Moderate Ownership } \\
\text { Concentration } \\
\text { Coeff ( } p \text {-value) } \\
\end{array}$ & $\begin{array}{l}\text { High Ownership } \\
\text { Concentration } \\
\text { Coeff ( } p \text {-value) } \\
\end{array}$ \\
\hline LnMVE & $0.019(0.016)^{b}$ & $0.023(0.001)^{\mathrm{a}}$ & $0.015(0.021)^{\mathrm{b}}$ \\
\hline$R O A$ & $0.024(0.596)$ & $-0.067(0.114)$ & $-0.076(0.265)$ \\
\hline LnSegments & $0.021(0.443)$ & $-0.025(0.315)$ & $0.019(0.415)$ \\
\hline$L E V$ & $-0.010(0.828)$ & $0.123(0.008)^{\mathrm{a}}$ & $0.034(0.487)$ \\
\hline FirmAge & $-0.001(0.458)$ & $0.000(0.894)$ & $-0.002(0.274)$ \\
\hline FirmAge $^{2}$ & $0.000(0.241)$ & $0.000(0.904)$ & $0.000(0.104)$ \\
\hline MTB & $-.004(0.269)$ & $-0.001(0.787)$ & $-0.004(0.046)^{b}$ \\
\hline$R \& D$ & $0.176(0.198)$ & $-0.283(0.088)^{\mathrm{C}}$ & $-0.155(0.509)$ \\
\hline STDRET & $-0.118(0.189)$ & $-0.301(0.004)^{\mathrm{a}}$ & $-0.151(0.173)$ \\
\hline CEO Own & $-0.001(0.145)$ & $-0.001(0.367)$ & $-0.001(0.002)^{\mathrm{a}}$ \\
\hline Director Own & $0.002(0.020)^{\mathrm{b}}$ & $0.002(0.005)^{\mathrm{a}}$ & $0.001(0.154)$ \\
\hline Free Cashflow & $-0.014(0.677)$ & $0.007(0.771)$ & $0.034(0.531)$ \\
\hline CEO Chair & $0.058(0.010)^{\mathrm{c}}$ & $0.032(0.166)$ & $0.004(0.870)$ \\
\hline Intercept & $0.281(0.050) \mathrm{b}$ & $0.213(0.122)$ & $0.481(0.000)^{\mathrm{a}}$ \\
\hline Industry dummies & Yes & Yes & Yes \\
\hline$N$ & 343 & 351 & 327 \\
\hline Model F-static ( $p$-value) & $3.797(0.000)$ & $3.098(0.000)$ & $2.044(0.004)$ \\
\hline Adj. $R^{2}$ & 0.152 & 0.116 & 0.066 \\
\hline Durbin-Watson statistic & 1.967 & 2.176 & 1.988 \\
\hline
\end{tabular}

Panel D: Ownership concentration and board leadership

\begin{tabular}{|c|c|c|c|}
\hline & $\begin{array}{l}\text { Low Ownership } \\
\text { Concentration } \\
\text { Coeff ( } p \text {-value ) } \\
\end{array}$ & $\begin{array}{c}\text { Moderate Ownership } \\
\text { Concentration } \\
\text { Coeff ( } p \text {-value) } \\
\end{array}$ & $\begin{array}{l}\text { High Ownership } \\
\text { Concentration } \\
\text { Coeff ( } p \text {-value) } \\
\end{array}$ \\
\hline LnMVE & $\begin{array}{ll}-0.401(0.000)^{\mathrm{a}} \\
\end{array}$ & $\begin{array}{ll}-0.283(0.001)^{\mathrm{a}} \\
\end{array}$ & $\begin{array}{l}-0.298(0.000)^{\mathrm{a}} \\
\end{array}$ \\
\hline$R O A$ & $0.516(0.242)$ & $-0.842(0.063)^{c}$ & $-0.148(0.786)$ \\
\hline LnSegments & $-0.397(0.273)$ & $-0.383(0.206)$ & $-0.916(0.003)^{\mathrm{a}}$ \\
\hline FirmAge & $0.029(0.301)$ & $0.077(0.035)^{\mathrm{b}}$ & $0.026(0.174)$ \\
\hline FirmAge $^{2}$ & $0.000(0.668)$ & $-0.001(0.184)$ & $0.000(0.748)$ \\
\hline MTB & $0.024(0.594)$ & $-0.022(0.542)$ & $-0.018(0.645)$ \\
\hline$R \& D$ & $-1.076(0.496)$ & $-1.839(0.449)$ & 2. $692(0.337)$ \\
\hline STDRET & $1.251(0.245)$ & $0.331(0.770)$ & $0.241(0.838)$ \\
\hline Intercept & $5.353(0.004)^{\mathrm{a}}$ & $3.468(0.030)^{\mathrm{b}}$ & $4.475(0.003)^{\mathrm{a}}$ \\
\hline Industry dummies & Yes & Yes & Yes \\
\hline$N$ & 356 & 367 & 355 \\
\hline Nagelkerke (1991) $R^{2}$ & 0.193 & 0.210 & 0.230 \\
\hline $\begin{array}{l}\text { Hosmer and Lemeshow test } \\
\text { statistic: } \chi^{2} \text { with } 8 \text { d.f. ( } p \text { - } \\
\text { value) }\end{array}$ & $14.177(0.077)$ & $3.062(0.930)$ & $11.005(0.201)$ \\
\hline $\begin{array}{l}\text { Correct classification \% by } \\
\text { model (naive prediction) }\end{array}$ & $72.5(67.7)$ & $70.8(66.5)$ & $73.2(66.8)$ \\
\hline \multicolumn{4}{|c|}{$\begin{array}{l}\text { a b and }{ }^{\mathrm{c}} \text { denote significance at the } 1 \%, 5 \% \text {, and } 10 \% \text { levels (two-tailed test). } \\
\text { Variable definition: Board Size = The number of members in the board of directors; Board Independence = The proportion } \\
\text { of nonexecutive directors in the board; CEO Duality (CEO Chair) = Dummy variable which takes a value of one when the } \\
\text { CEO is also the board chair; LnMVE = Natural logarithm of market value of equity; Total Assets = Book value of total assets } \\
\text { at the end of 2006; LEV = Leverage ratio = Total Liabilities divided by Total Assets; } R O A=\text { Earnings Before Interest and } \\
\text { Taxes divided by Total Assets; FirmAge = The number of years the firm has been listed at the Australian Securities } \\
\text { Exchange till the end of } 2006 \text { fiscal-year; LnSegments = The number of business segments in the firm; Market-to-Book } \\
\text { ratio = Market-to-book ratio of equity; R\&D = R\&D expenditures /Total Assets; STDRET = Standard deviation of monthly } \\
\text { stock returns over the preceding fiscal year; Free Cashflow = Operating cash flow less net capital investments during the } \\
\text { year scaled by Total Assets; CEO Own = The percentage of firm shares owned by the CEO; Director Own = The percentage } \\
\text { of firm shares owned by the directors other than the CEO; Top20 Own = The percentage of firm shares owned by the Top } 20 \\
\text { shareholders; CEO Age = CEO's age measured in years; CEO Tenure = The number of years the CEO held the current } \\
\text { position in the firm; Industry Dummies = Dummy variables to capture the differences in board structure due to industry } \\
\text { characteristics; Industry classification is based on Standard \& Poor's two-digit Global Industry Classification Scheme } \\
\text { (GICS). }\end{array}$} \\
\hline
\end{tabular}

